\title{
NUTRIENT EXTRACTION AND EXPORTATION BY COMMON BEAN CULTIVARS UNDER DIFFERENT FERTILIZATION LEVELS: II - MICRONUTRIENTS ${ }^{(1)}$
}

\author{
Adalton Mazetti Fernandes ${ }^{(2)}$, Rogério Peres Soratto $^{(3)}$ \& Letícia Andriani dos Santos ${ }^{(4)}$
}

\begin{abstract}
SUMMARY
Where the level of agricultural technology is higher, common bean cultivars with a higher yield potential possibly require greater amounts of micronutrients. In Brazil however, there is a lack of information about the micronutrient extraction and exportation by the main grown cultivars. The objective of this study was to evaluate micronutrient ( $\mathrm{B}, \mathrm{Cu}, \mathrm{Fe}, \mathrm{Mn}$, and $\mathrm{Zn}$ ) extraction and exportation by common bean cultivars Pérola and IAC Alvorada, under different levels of NPK fertilization, on a dystroferric Red Nitosol, in Botucatu, São Paulo State, Brazil. The experiment was arranged in a randomized complete block (split plot) design with four replications. The plots consisted of six treatments based on a $2 \times 3$ factorial model, represented by two cultivars and three NPK levels (PD0 - 'Pérola' without fertilization, PD1 - 'Pérola' with $50 \%$ of recommended fertilization, PD2 - 'Pérola' with $100 \%$ of recommended fertilization, AD0 - 'IAC Alvorada' without fertilization, AD1 - 'IAC Alvorada' with $50 \%$ of recommended fertilization, and AD2 - 'IAC Alvorada' with $100 \%$ of recommended fertilization) and subplots sampled seven times during the cycle. Higher levels of NPK fertilization increased micronutrient extraction by both cultivars, and treatments with $100 \%$ of recommended NPK fertilization extracted on average $167 \mathrm{~g} \mathrm{~B}, 58 \mathrm{~g} \mathrm{Cu}, 1,405 \mathrm{~g} \mathrm{Fe}, 1,213 \mathrm{~g} \mathrm{Mn}$ and $211 \mathrm{~g} \mathrm{Zn}$ per hectare. Regardless of the treatment, the highest demand period for $B, C u, F e, M n$ and $\mathrm{Zn}$ in both cultivars occurred at the $R_{7}$ stage (pod formation), i.e. 42 to 55 days after emergence (DAE). The amount of $\mathrm{B}, \mathrm{Cu}, \mathrm{Fe}, \mathrm{Mn}$ and $\mathrm{Zn}$ exported depended mainly on the level of NPK fertilization used, with values per hectare ranging from 38 to $90 \mathrm{~g}$ of $\mathrm{B}, 12$ to $26 \mathrm{~g}$ of $\mathrm{Cu}, 222$ to $568 \mathrm{~g}$ of $\mathrm{Fe} 234$ to $467 \mathrm{~g}$ of $\mathrm{Mn}$, and 40 to $96 \mathrm{~g}$ of $\mathrm{Zn}$.
\end{abstract}

Index terms: Phaseolus vulgaris, mineral nutrition, absorption curves, absorption rates, nutrients accumulation.

\footnotetext{
(1) Received for publication on November 19, 2012 and approved on April 26, 2013.

(2) Doctorate in Agronomy (Agriculture), College of Agricultural Sciences, São Paulo State University - FCA/UNESP, P.O. Box 37. CEP 18610-307 Botucatu (SP), Brazil. E-mail: adaltonfernandes@hotmail.com

(3) Associate Professor at Department of Crop Science, FCA/UNESP. Research award from CNPq. E-mail: soratto@fca.unesp.br

(4) Graduate in Agronomy, FCA/UNESP. E-mail: leticiaandriani@hotmail.com
} 


\title{
RESUMO: EXTRAÇÃO E EXPORTAÇÃO DE NUTRIENTES EM CULTIVARES DE FEIJOEIRO, SOB NÍVEIS DE ADUBAÇÃO: II - MICRONUTRIENTES
}

\begin{abstract}
Sob maior nível tecnológico, cultivares de feijão com maior potencial produtivo possivelmente exigem maior quantidade de micronutrientes. Porém, no Brasil há carência de informações sobre extração e exportação de micronutrientes pelos principais cultivares utilizados. Neste estudo, objetivou-se avaliar a extração e a exportação de micronutrientes ( $\mathrm{B}, \mathrm{Cu}, \mathrm{Fe}, \mathrm{Mn}$ e Zn) pelos cultivares de feijão Pérola e IAC Alvorada, sob diferentes níveis de adubação NPK, em um Nitossolo Vermelho distroférrico, no município de Botucatu, SP. O delineamento experimental utilizado foi de blocos casualizados, em esquema de parcela subdividida, com quatro repetições. As parcelas foram constituídas por seis tratamentos referentes a um fatorial $2 \times 3$, sendo dois cultivares e três níveis de adubação NPK (PDO - 'Pérola' sem adubação NPK, PD1 - 'Pérola' com $50 \%$ da adubação recomendada, PD2 - 'Pérola' com $100 \%$ da adubação recomendada, ADO - 'IAC Alvorada' sem adubação, AD1 - 'IAC Alvorada' com $50 \%$ da adubação recomendada e AD2 - 'IAC Alvorada' com $100 \%$ da adubação recomendada) e as subparcelas, por sete épocas de coletas no decorrer do ciclo. Maiores níveis de adubação NPK aumentaram a extração de micronutrientes pelos dois cultivares; no entanto, $100 \%$ adubação NPK recomendada proporcionou extração média de $167 \mathrm{~g}$ de $\mathrm{B}, 58 \mathrm{~g}$ de Cu, $1.405 \mathrm{~g}$ de Fe, $1.213 \mathrm{~g}$ de $\mathrm{Mn}$ e $211 \mathrm{~g}$ de Zn por hectare. Independentemente do tratamento, a época de maior demanda por $\mathrm{B}, \mathrm{Cu}, \mathrm{Fe}, \mathrm{Mn}$ e $\mathrm{Zn}$, em ambos os cultivares, ocorreu no estádio $R_{7}$ (formação das vagens), ou seja, de 42 a 55 dias, após a emergência (DAE). A quantidade de B, Cu, Fe, Mn e Zn exportada foi dependente, principalmente, do nível de adubação NPK utilizado, com valores por hectare variando de 38 a $90 \mathrm{~g}$ de B, 12 a 26 g de Cu, 222 a 568 g de Fe, 234 a 467 g de Mn e 40 a $96 \mathrm{~g}$ de $\mathrm{Zn}$.
\end{abstract}

Termos de indexação: Phaseolus vulgaris, nutrição mineral, curvas de absorção, taxas de absorção, acúmulo de nutrientes.

\section{INTRODUCTION}

In Brazil, common bean (Phaseolus vulgaris L.) is no longer considered only a subsistence crop. Currently, this crop is also grown by farmers in medium and large areas, using advanced technology such as irrigation, higher levels of fertilization and cultivars with a high yield potential, resulting in grain yields above $3,000 \mathrm{~kg} \mathrm{ha}^{-1}$ (Vieira, 2006; Fernandes et al., 2007). The nutrient demand and exportation under these conditions are possibly different from those of low-yielding crops (Gallo \& Miyasaka, 1961; Haag et al., 1967; Cobra Netto et al., 1971; Rosolem, 1987).

Despite the increase in technology used by farmers for common bean cultivation, mineral nutrition is often overlooked, especially of micronutrients (Teixeira et al., 2004; Fernández et al., 2007; Ascoli et al., 2008). However, micronutrients are essential for crop growth and development (Kirkby \& Römheld, 2007), and a low availability of any micronutrient in the soil leads to a decrease in the common bean yield (Oliveira et al., 1996).

To date, studies about nutrient absorption by common bean were restricted to macronutrients only, although they were developed in the 1960's and 1970's, when grain yield was low (Gallo \& Miyasaka, 1961; Haag et al., 1967; Cobra Netto et al., 1971). Absorption and accumulation of micronutrients were investigated with common bean, but these studies were conducted in pots, or only the micronutrient extraction at flowering and the exportation of these elements by harvested grains were determined (Fageria, 1989; Fageria \& Souza, 1995; Barbosa Filho \& Silva, 2000). Therefore, information on the demand for micronutrients during the crop cycle under field conditions and with high levels of grain yield is scarce.

Thus, current studies are needed about the mineral nutrition of common bean, especially with regard to micronutrients, since these become increasingly important as grain yield levels are increased (Barbosa \& Gonzaga, 2012). Studying micronutrient absorption during the development cycle of the current common bean cultivars, grown at different levels of fertilization, is essential, underlying the definition of the absorbed amounts, the times of greatest demand and the distribution of nutrients in the different plant structures. This information will help establish more rational fertilization programs for specific growth conditions, to increase fertilizer use efficiency, reduce costs and to maintain soil fertility.

The objective of this study was to evaluate the micronutrient ( $\mathrm{B}, \mathrm{Cu}, \mathrm{Fe}, \mathrm{Mn}$, and $\mathrm{Zn}$ ) extraction and exportation by the common bean cultivars Pérola and IAC Alvorada, under different levels of NPK fertilization. 


\section{MATERIALS AND METHODS}

A field experiment was conducted on the Experimental Farm Lageado of the College of Agricultural Sciences - São Paulo State University, in Botucatu, São Paulo State, Brazil $\left(48^{\circ} 26^{\prime}\right.$ W, $22^{\circ} 51^{\prime} \mathrm{S}, 740 \mathrm{~m}$ asl), in a dystroferric Red Nitosol (Embrapa, 2006). According to the Köppen classification, the climate is Cwa (tropical highland), with a dry winter and a hot, rainy summer. The experiment was carried out in an area under no-tillage cultivation for several years. Before the installation of this experiment, wheat/maize/pearl millet crops were grown in the area.

Prior to the experiment, a soil sample consisting of 10 subsamples was taken in the $0-20 \mathrm{~cm}$ layer to determine the chemical properties (Raij et al., 2001): organic matter $=28 \mathrm{~g} \mathrm{dm}^{-3} ; \mathrm{pH}\left(\mathrm{CaCl}_{2} 0.01 \mathrm{~mol} \mathrm{~L}^{-1}\right)$ $=5.0 ; \mathrm{P}($ resin $)=33 \mathrm{mg} \mathrm{dm}{ }^{-3} ; \mathrm{K}^{+}=3.0 \mathrm{mmol}_{\mathrm{c}} \mathrm{dm}^{-3}$; $\mathrm{Ca}^{2+}=25 \mathrm{mmol}_{\mathrm{c}} \mathrm{dm}^{-3} ; \mathrm{Mg}^{2+}=11 \mathrm{mmol}_{\mathrm{c}} \mathrm{dm}^{-3} ; \mathrm{H}+\mathrm{Al}$ $=32 \mathrm{mmol}_{\mathrm{c}} \mathrm{dm}^{-3} ;$ base saturation $=55 \% ; \mathrm{S}=6.4$ $\mathrm{mg} \mathrm{dm}{ }^{-3} ; \mathrm{B}=0.40 \mathrm{mg} \mathrm{dm}^{-3} ; \mathrm{Cu}=12.4 \mathrm{mg} \mathrm{dm}^{-3} ; \mathrm{Fe}$ $=23 \mathrm{mg} \mathrm{dm}^{-3} ; \mathrm{Mn}=5.1 \mathrm{mg} \mathrm{dm}^{-3} ;$ and $\mathrm{Zn}=1.6 \mathrm{mg} \mathrm{dm}^{-3}$.

Fertilization at sowing was $20 \mathrm{~kg} \mathrm{ha}^{-1} \mathrm{~N}$ (urea), 40 $\mathrm{kg} \mathrm{ha}^{-1} \mathrm{P}_{2} \mathrm{O}_{5}$ (triple superphosphate), and $40 \mathrm{~kg} \mathrm{ha}^{-1}$ $\mathrm{K}_{2} \mathrm{O}$ (potassium chloride), according to soil analysis and following the recommendation of Ambrosano et al. (1997), for an expected grain yield of 3,500$4,500 \mathrm{~kg} \mathrm{ha}^{-1}$. The recommendation for the topdressing fertilizer was $90 \mathrm{~kg} \mathrm{ha}^{-1} \mathrm{~N}$ (urea), considering the area as a high expected response to $\mathrm{N}$ application (Ambrosano et al., 1997). No S or micronutrient fertilization was applied.

The experiment was arranged in a randomized complete block design with split-plots and four replications. Plots consisted of six treatments in a $2 \times 3$ factorial arrangement, consisting of two cultivars and three NPK levels (PD0 - Pérola without NPK fertilization, PD1 - Pérola with $50 \%$ of recommended NPK fertilization; PD2 - Pérola with $100 \%$ of recommended NPK fertilization; AD0 - IAC Alvorada without NPK fertilization, AD1 IAC Alvorada with $50 \%$ of recommended NPK fertilization, and AD2 - IAC Alvorada with $100 \%$ of recommended NPK fertilization). Subplots consisted of seven plant sampling (evaluations) times, (Table 1). Each plot consisted of five $12 \mathrm{~m}$-long rows, spaced $0.45 \mathrm{~m}$ apart $\left(27 \mathrm{~m}^{2}\right)$; the three central rows of each plot were evaluated, without the borders of $0.5 \mathrm{~m}$ at either end of each row $(14.8 \mathrm{~m})$. Each subplot was represented by six plants sampled per plot. The plants from the surroundings of the sampled plants were not used.

Sowing was performed mechanically on $02 / 15 / 2011$ ( 15 seeds per meter). In all treatments, the seeds were treated with the fungicide carbendazim + thiram (45 + $105 \mathrm{~g}$ a.i. per $100 \mathrm{~kg}$ of seed) and the insecticide thiamethoxam ( $75 \mathrm{~g}$ a.i. per $100 \mathrm{~kg}$ of seed). Seedling emergence occurred on 02/22/2011. A topdressing fertilization of nitrogen was split in two applications, one 14 days after emergence (DAE) and the second 24 DAE (V4 stage). Irrigation and phytossanitary management during the crop cycle were performed as needed and according to the technical recommendations.

At common bean flowering (37 DAE), leaves were collected as described by Ambrosano et al. (1997), and concentrations of $\mathrm{B}, \mathrm{Cu}, \mathrm{Fe}, \mathrm{Mn}$, and $\mathrm{Zn}$ were determined according to Malavolta et al. (1997).

At each sampling time, the shoots of six plants without symptoms of damage caused by pests and diseases and surrounded by healthy plants on all sides - were collected per plot. Stems, leaves and reproductive structures (pods + grains) of the sampled plants were separated. The plant parts were dried separately in a forced-air oven at $65^{\circ} \mathrm{C}$ for $72 \mathrm{~h}$ and weighed. The data regarding dry matter (DM) associated with the times of plant sampling were used to obtain the curves of DM accumulation (Soratto et al., 2013).

The samples were ground in a Willey mill and the micronutrient concentrations $(\mathrm{B}, \mathrm{Cu}, \mathrm{Fe}, \mathrm{Mn}$, and $\mathrm{Zn}$ ) were determined according to Malavolta et al. (1997). The amounts of accumulated micronutrients were estimated for all compartments of the aboveground part of the plant (shoot) separately and together, using data from the micronutrient concentration and amounts of DM accumulated. Accumulation rates of micronutrients in the reproductive structures and shoot were obtained by the first derivative of the adjustment equations.

At the end of the cycle (90 DAE), the grain yield was determined in two 3-m-long rows of each plot (Soratto et al., 2013). A sample of grains from each plot was dried in a forced-air oven at $65{ }^{\circ} \mathrm{C}$ for $72 \mathrm{~h}$. Afterwards, these grains were ground and micronutrient ( $\mathrm{B}, \mathrm{Cu}, \mathrm{Fe}, \mathrm{Mn}$, and $\mathrm{Zn}$ ) concentration was determined according to Malavolta et al. (1997). Micronutrient exportation was obtained using the data of grain yield DM (Soratto et al., 2013) and micronutrient concentration in grains.

Data were subjected to analysis of variance. The means of the treatments at each sampling time were separated by the LSD test at 0.05 probability, using the Sisvar software. The effects of plant sampling times were evaluated by regression analysis, using SigmaPlot 10.0 software.

\section{RESULTS AND DISCUSSION}

Boron concentration in plant leaves from treatment $\mathrm{AD0}\left(32 \mathrm{mg} \mathrm{kg}^{-1}\right)$ was higher than in PD1 (24 mg kg-1), PD2 (28 mg kg-1), and AD1 (27 mg kg-1), but did not differ significantly from the other treatments (Table 2). Despite the differences among treatments, 
Table 1. Description of the common bean growth stages in each time of evaluation

\begin{tabular}{ccl}
\hline Time of evaluation & Growth stage ${ }^{(\mathbf{1})}$ & Plant characteristics in each time of evaluation \\
\hline $\mathrm{DAE}^{(2)}$ & & \\
14 & $\mathrm{~V}_{4}$ & Third trifoliate leaf expanded \\
28 & $\mathrm{R}_{5}$ & Pre-flowering (flower buds) \\
35 & End of $\mathrm{R}_{5}$ & Pre-flowering (a little before to full flowering) \\
42 & Early $\mathrm{R}_{7}$ & Beginning of pod formation \\
55 & End of $\mathrm{R}_{7}$ & End of pod formation \\
70 & $\mathrm{R}_{8}$ & Grain filling \\
90 & $\mathrm{R}_{9}$ & Maturation \\
\hline
\end{tabular}

(1) Fernández et al. (1986). ${ }^{(2)}$ Days after emergence.

Table 2. Concentration of micronutrients $(\mathrm{B}, \mathrm{Cu}, \mathrm{Fe}$, $\mathrm{Mn}$ and $\mathrm{Zn})$ in leaf diagnosis, collected at $\mathrm{R6}$ stage (37 DAE), of common bean cultivars under different levels of fertilization

\begin{tabular}{ccrcrl}
\hline Treatment $^{(1)}$ & $\mathbf{B}$ & $\mathbf{C u}$ & $\mathbf{F e}$ & Mn & Zn \\
\hline & \multicolumn{5}{c}{$\mathrm{mg} \mathrm{kg}^{-1}$} \\
\cline { 2 - 6 } PD0 & $29 \mathrm{abc}$ & $8 \mathrm{a}$ & $224 \mathrm{ab}$ & $86 \mathrm{~b}$ & $31 \mathrm{~b}$ \\
PD1 & $24 \mathrm{~d}$ & $10 \mathrm{a}$ & $144 \mathrm{c}$ & $124 \mathrm{a}$ & $34 \mathrm{ab}$ \\
PD2 & $28 \mathrm{bc}$ & $9 \mathrm{a}$ & $171 \mathrm{bc}$ & $116 \mathrm{a}$ & $35 \mathrm{a}$ \\
AD0 & $32 \mathrm{a}$ & $10 \mathrm{a}$ & $231 \mathrm{a}$ & $90 \mathrm{~b}$ & $31 \mathrm{~b}$ \\
AD1 & $27 \mathrm{c}$ & $10 \mathrm{a}$ & $182 \mathrm{abc}$ & $123 \mathrm{a}$ & $30 \mathrm{~b}$ \\
AD2 & $30 \mathrm{ab}$ & $10 \mathrm{a}$ & $134 \mathrm{c}$ & $118 \mathrm{a}$ & $32 \mathrm{ab}$ \\
CV (\%) & 6.8 & 7.8 & 21.8 & 11.4 & 8.3 \\
\hline
\end{tabular}

Values followed by same letter in columns, are not significantly different at $\mathrm{p} \leq 0.05$ according to LSD test. ${ }^{(1)} \mathrm{PD} 0=$ Pérola without NPK fertilization, PD1 = Pérola with $50 \%$ of recommended NPK fertilization; Pérola PD2 = Pérola with $100 \%$ of recommended NPK fertilization; AD0 = IAC Alvorada without NPK fertilization, AD1 = IAC Alvorada with $50 \%$ of recommended NPK fertilization; AD2 = IAC Alvorada with $100 \%$ of recommended NPK fertilization.

in treatment PD1, the B concentration in leaves was within the range of $15-26 \mathrm{mg} \mathrm{kg}^{-1}$, which is considered appropriate by Ambrosano et al. (1997). In the other treatments, the B concentration in the leaves was above this range. The high $\mathrm{B}$ concentrations, especially in the treatments without NPK fertilization, may be due to a concentration effect, once the DM production in these treatments was lower (Soratto et al., 2013). The copper concentration in leaves was not affected by treatments, but in all treatments the $\mathrm{B}$ concentration was within the range considered appropriate for common bean (4-20 mg kg-1) (Ambrosano et al., 1997).

In treatment $\mathrm{AD} 0$, the $\mathrm{Fe}$ concentration in leaves was higher than in PD1, PD2, and AD2, but similar to the other treatments (Table 2). Only in AD2, the Fe leaf concentration was within the range proposed by Ambrosano et al. (1997) (40-140 $\mathrm{mg} \mathrm{kg}^{-1}$ ), while in all other treatments, the Fe concentrations were higher than the values reported by these authors. Soratto \&
Crusciol (2008) also observed higher the Fe leaf concentrations of common bean cultivars than the appropriate range proposed by Ambrosano et al. (1997). This result may be due to the high $\mathrm{Fe}$ availability in the soil $\left(23 \mathrm{mg} \mathrm{dm}^{-3}\right)$. In treatments without NPK fertilization, the Mn concentration in leaves of both cultivars (PD0 and AD0) was similar, but lower than in the fertilized treatments, indicating no significant difference in $\mathrm{Mn}$ concentrations (Table 2). Treatments without NPK fertilization showed Mn leaf concentrations in the range of 15 to $100 \mathrm{mg} \mathrm{kg}^{-1}$, considered appropriate by Ambrosano et al. (1997), however, in treatments with NPK fertilization, the Mn concentration was higher than the appropriate range. The zinc leaf concentrations in treatment PD2 were significantly different from PD0, AD0, and AD1 (Table 2), although the $\mathrm{Zn}$ concentrations in all treatments were within the range considered appropriate by Ambrosano et al. (1997) (18 - $\left.50 \mathrm{mg} \mathrm{kg}^{-1}\right)$.

In general, micronutrient concentrations in leaves in all treatments were similar and/or higher than the values considered adequate for common bean, which result from the availability of these micronutrients in the soil, considered medium (B) to high $(\mathrm{Cu}, \mathrm{Fe}$, Mn, and Zn) (Raij et al., 1997). These results indicate that the availability of micronutrients was adequate in the soil and there was no limitation to adequate absorption of these micronutrients by common bean.

With regard to micronutrient absorption, it was noted that regardless of the treatment, the amount accumulated in the stem increased up to 70-75 DAE (R8) and decreased slightly in the following stages (Figures 1a, 2a, 3a, 4a, and 5a). Treatments showed no significant difference in the amounts of micronutrients accumulated in the stem during the first $28 \mathrm{DAE}$, but from the beginning of flowering, i.e., $35 \mathrm{DAE}$, the amounts accumulated in stems in the case of the treatments with $100 \%$ of recommended NPK fertilization were higher than the amount obtained in treatments without fertilization. In treatments with half the recommended NPK fertilization, the accumulated amounts of micronutrients in the stem were intermediate. 


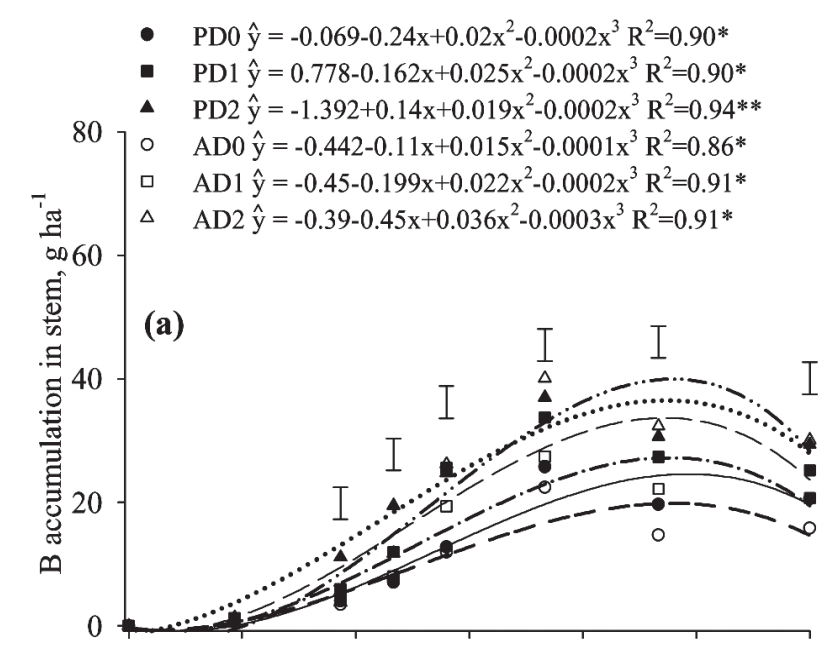

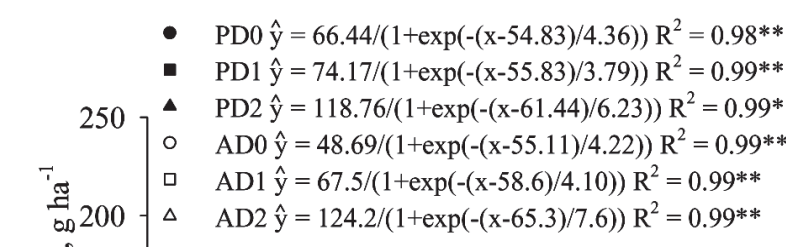

$$
\text { 莕 }
$$

0
0
0
0
0 150

0

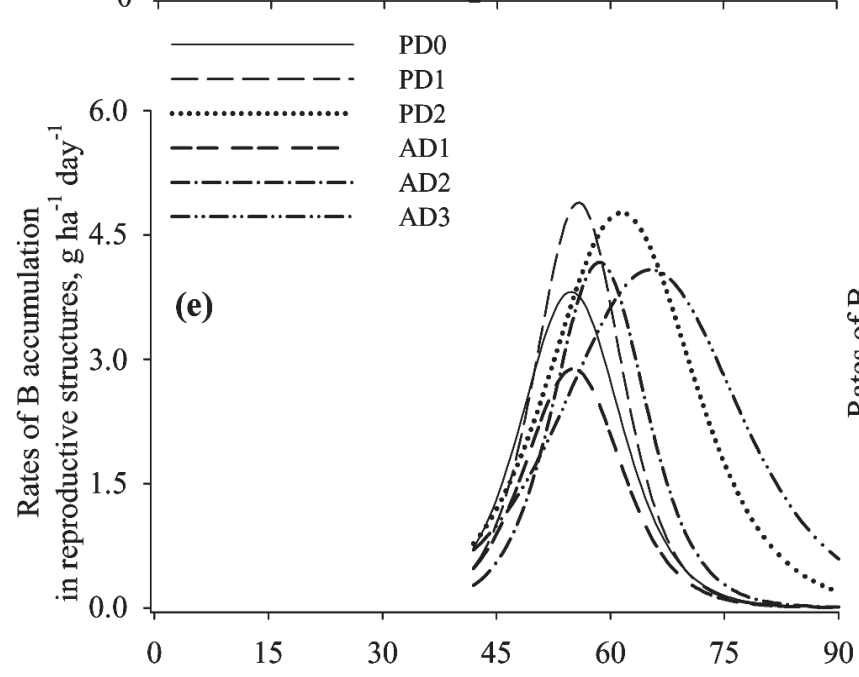

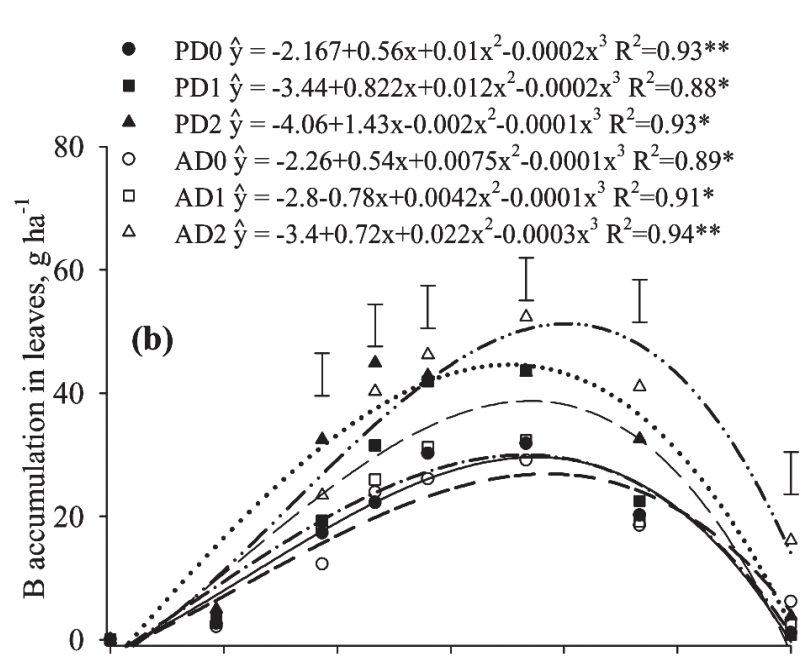

- $\quad \mathrm{PD} 0 \hat{\mathrm{y}}=109.01 \exp \left(-0.5((\mathrm{x}-74.33) / 25.15)^{2}\right) \mathrm{R}^{2}=0.98^{* *}$

- $\quad P D 1 \hat{y}=128.68 \exp \left(-0.5((x-71.57) / 25.21)^{2}\right) \mathrm{R}^{2}=0.99 * *$

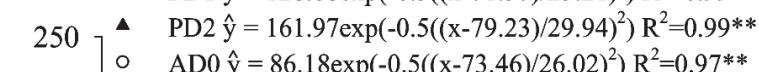

'־ $200-\triangle \quad A D 1 \hat{y}=107.0 \exp \left(-0.5((x-74.9) / 26.3)^{2}\right) R^{2}=0.99 * *$
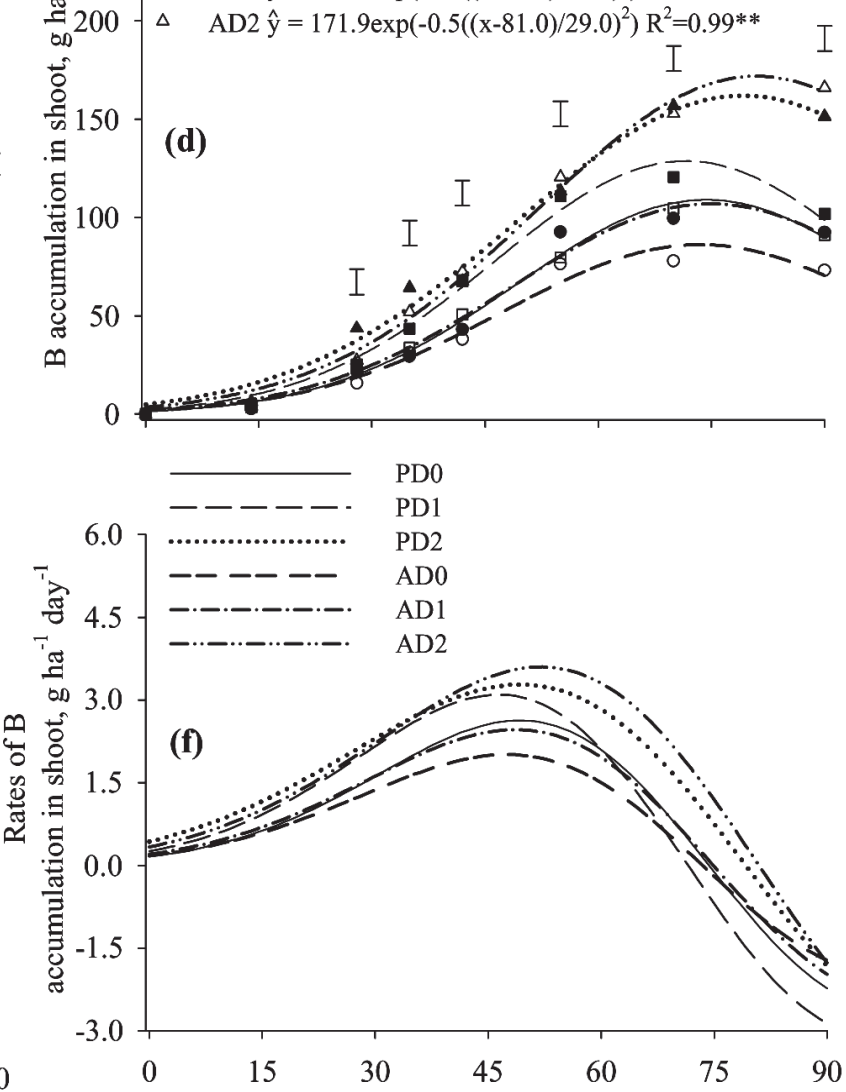

Day after emergence

Figure 1. Boron accumulationin stem (a), leaves (b), reproductive structures (c), and shoot (d) and rates of accumulation of $B$ in reproductive structures (e) and shoot (f) of common bean cultivars, under different levels of fertilization. $* *$ and $*$ are: significant at $p \leq 0.01$ and $p \leq 0.05$ by the F test. Vertical bars represent the Least Significant Difference (LSD) at $p \leq 0.05$. PDo = Pérola without NPK fertilization, PD1 = Pérola with $50 \%$ of recommended NPK fertilization; PD2 = Pérola with $100 \%$ of recommended NPK fertilization; AD0 = IAC Alvorada without NPK fertilization, AD1 = IAC Alvorada with $50 \%$ of recommended NPK fertilization; AD2 = IAC Alvorada with $100 \%$ of recommended NPK fertilization. 

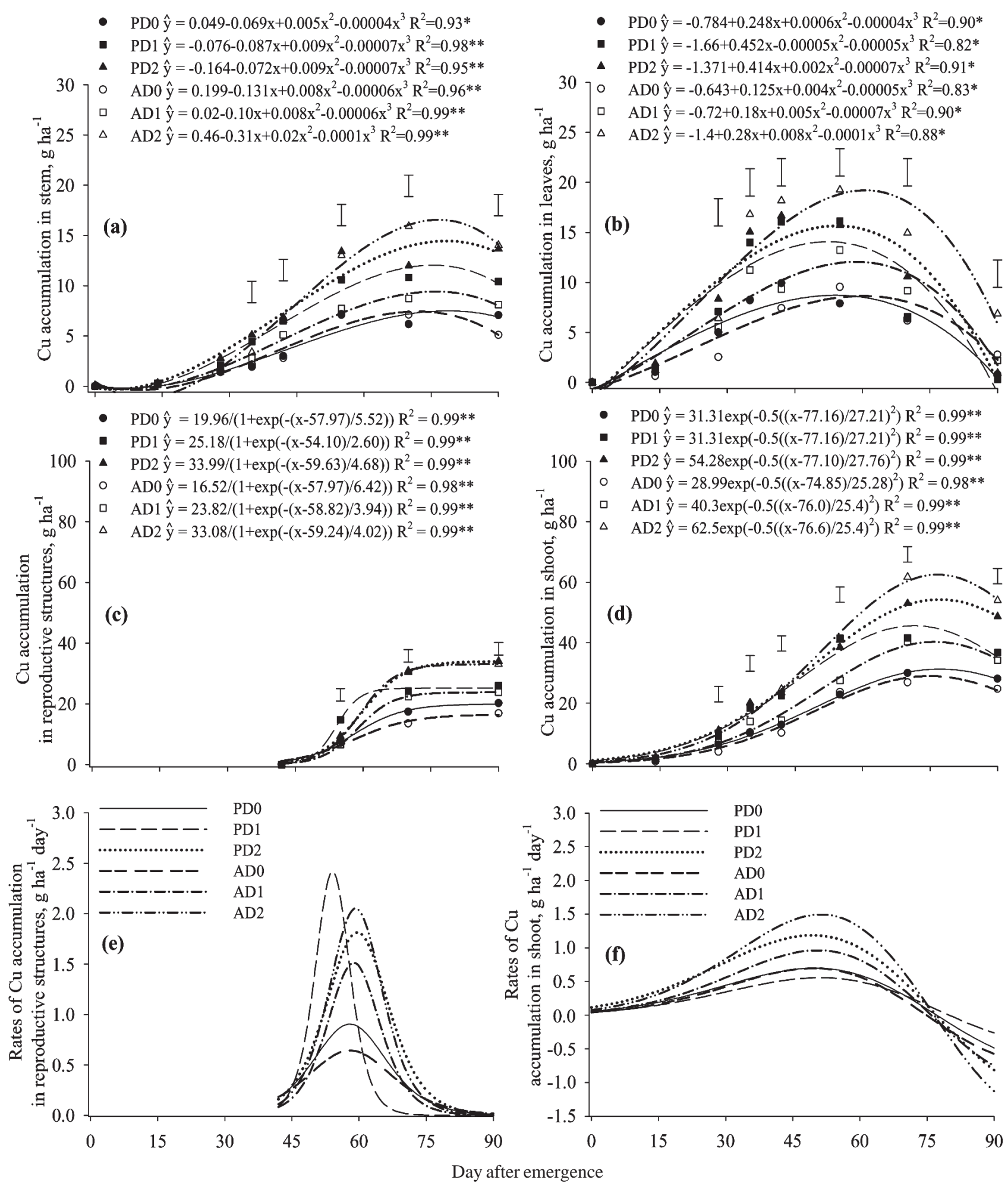

Figure 2. Copper accumulationin stem (a), leaves (b), reproductive structures (c), and shoot (d) and rates of accumulation of $\mathrm{Cu}$ in reproductive structures (e) and shoot (f) of common bean cultivars, under different levels of fertilization. ** and * are: significant at $p \leq 0.01$ and $p \leq 0.05$ by the $F$ test. Vertical bars represent the Least Significant Difference (LSD) at $\mathbf{p} \leq \mathbf{0 . 0 5}$. PDO $=$ Pérola without NPK fertilization, PD1 = Pérola with $50 \%$ of recommended NPK fertilization; PD2 = Pérola with $100 \%$ of recommended NPK fertilization; AD0 = IAC Alvorada without NPK fertilization, AD1 = IAC Alvorada with $50 \%$ of recommended NPK fertilization; AD2 = IAC Alvorada with $100 \%$ of recommended NPK fertilization. 

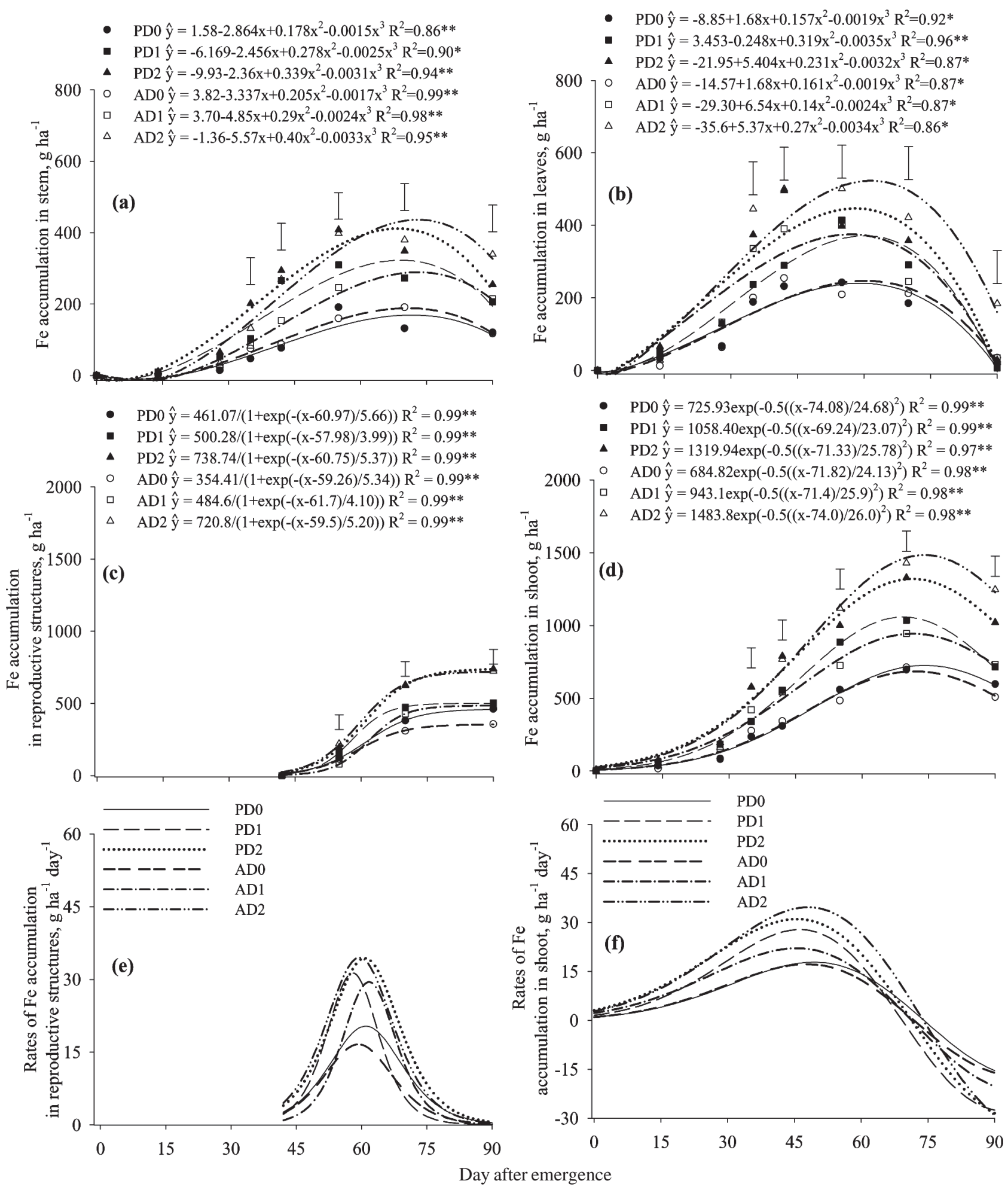

Figure 3. Iron accumulationin stem (a), leaves (b), reproductive structures (c), and shoot (d) and rates of accumulation of $\mathrm{Fe}$ in reproductive structures (e) and shoot (f) of common bean cultivars, under different levels of fertilization. ${ }^{* *}$ and * are: significant at $p \leq 0.01$ and $p \leq 0.05$ by the $F$ test. Vertical bars represent the Least Significant Difference (LSD) at $p \leq 0.05$. PDo $=$ Pérola without NPK fertilization, PD1 = Pérola with $50 \%$ of recommended NPK fertilization; PD2 = Pérola with $100 \%$ of recommended NPK fertilization; AD0 = IAC Alvorada without NPK fertilization, AD1 = IAC Alvorada with $50 \%$ of recommended NPK fertilization; AD2 = IAC Alvorada with $100 \%$ of recommended NPK fertilization. 

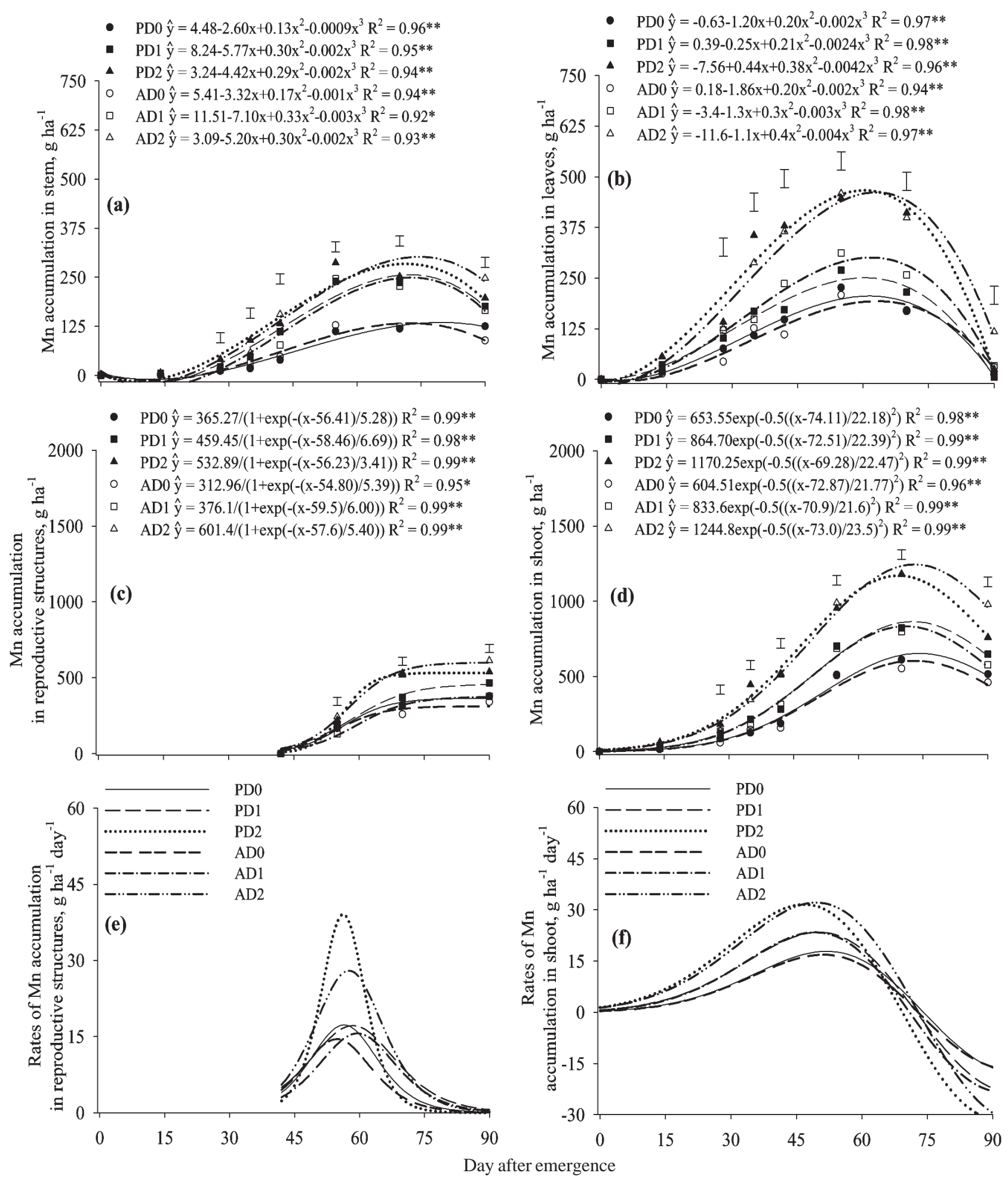

Figure 4. Manganese accumulationin stem (a), leaves (b), reproductive structures (c), and shoot (d) and rates of accumulation of $\mathrm{Mn}$ in reproductive structures (e) and shoot (f) of common bean cultivars, under different levels of fertilization. ${ }^{* *}$ and $*$ are: significant at $\mathbf{p} \leq 0.01$ and $\mathbf{p} \leq 0.05$ by the $\mathbf{F}$ test. Vertical bars represent the Least Significant Difference (LSD) at $\mathbf{p} \leq 0.05$. PDO = Pérola without NPK fertilization, PD1 = Pérola with $50 \%$ of recommended NPK fertilization; PD2 = Pérola with $100 \%$ of recommended NPK fertilization; AD0 = IAC Alvorada without NPK fertilization, AD1 = IAC Alvorada with $50 \%$ of recommended NPK fertilization; AD2 = IAC Alvorada with $100 \%$ of recommended NPK fertilization. 

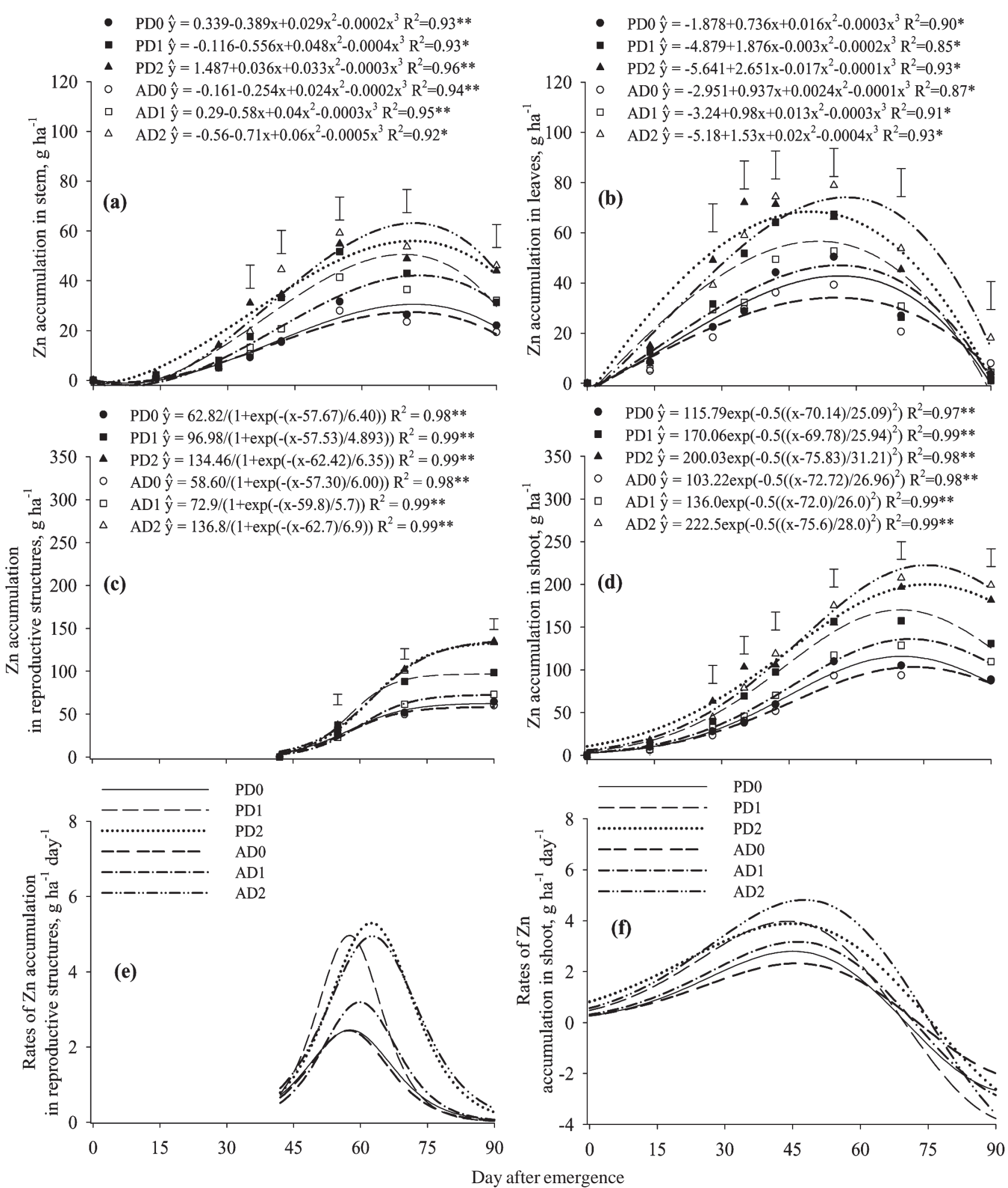

Figure 5. Zinc accumulationin stem (a), leaves (b), reproductive structures (c), and shoot (d) and rates of accumulation of $\mathrm{Zn}$ in reproductive structures (e) and shoot (f) of common bean cultivars, under different levels of fertilization. ** and * are: significant at $p \leq 0.01$ and $p \leq 0.05$ by the $F$ test. Vertical bars represent the Least Significant Difference (LSD) at $\mathbf{p} \leq \mathbf{0 . 0 5}$. PDo $=$ Pérola without NPK fertilization, PD1 = Pérola with $50 \%$ of recommended NPK fertilization; PD2 = Pérola with $100 \%$ of recommended NPK fertilization; AD0 = IAC Alvorada without NPK fertilization, AD1 = IAC Alvorada with $50 \%$ of recommended NPK fertilization; AD2 = IAC Alvorada with $100 \%$ of recommended NPK fertilization. 
In leaves, the accumulated amounts of $\mathrm{Cu}, \mathrm{Fe}$, and $\mathrm{Zn}$ increased up to 50 and $60 \mathrm{DAE}$ (R7), while the amounts of Mn increased up to 60 and $65 \mathrm{DAE}$ (Figures 1b, 2b, 3b, 4b, and 5b), i.e., the maximum leaf accumulations occurred between the stages R7 (pod formation) and R8 (grain filling). After these stages, the amounts of micronutrients accumulated in leaves decreased due to leaf senescence and abscission. In general, at each fertilization level studied there was no difference between cultivars concerning the amounts of micronutrients accumulated in leaves. However, treatments with $100 \%$ of recommended NPK fertilization showed higher accumulations in leaves. Lower accumulations of micronutrients in leaves occurred mainly in treatments without fertilization. In treatments with $50 \%$ of recommended NPK fertilization, the amounts of micronutrients accumulated in leaves were intermediate, but did not differ significantly from treatments without fertilization and/or with recommended NPK fertilization, during most of the cycle.

Regardless of the treatment, the micronutrients which accumulated highest amounts in the stems and leaves of common bean were Fe and Mn (Figures 1a,b; 2a,b; 3a,b; 4a,b; and 5a,b). Fageria (1989) also observed a higher accumulation of $\mathrm{Fe}$ and $\mathrm{Mn}$ in the shoot (represented by the leaves and stems) than in grains and pods of common bean plants grown at different $P$ levels in a pot study. The amounts of these micronutrients accumulated in the vegetative part, i.e., in the leaves and stem, were higher than the amounts in the reproductive structures (Figures 1c, $2 \mathrm{c}, 3 \mathrm{c}, 4 \mathrm{c}$, and $5 \mathrm{c}$ ). This higher accumulation of $\mathrm{Fe}$ and $\mathrm{Mn}$ in leaves and stem is related to their functions in plant metabolism. Iron acts in the synthesis of chlorophyll, and participates in photosynthesis and respiration (Malavolta, 2006; Dechen \& Nachtigall, 2006). After absorption, Fe is transported over long distances by the xylem and its mobilization into the phloem is decreased by the formation of insoluble compounds in the leaves (Dechen \& Nachtigall, 2006). Therefore, $\mathrm{Fe}$ is accumulated mainly in leaves which are the site of the primary function of this nutrient (Kirkby \& Römheld, 2007). Manganese acts as an enzyme activator in the respiration process and participates in the photosynthesis process (Malavolta, 2006). Thus, the higher amounts of $\mathrm{Mn}$ in the vegetative part, i.e., in leaves and stem, are due to its low redistribution in the plant. This micronutrient, after being absorbed, moves through the transpiration stream and accumulates in certain plant organs such as leaves (Malavolta, 2006). Moreover, the low quantity transported through the phloem is responsible for the low concentration of this nutrient in fruits, seeds and storage organs (Dechen \& Nachtigall, 2006). Once Mn is incorporated or immobilized in the leaves it cannot be remobilized, not even under induced senescence (Wood et al., 1986).
In the reproductive structures, the amounts of $\mathrm{Cu}$, $\mathrm{Fe}$, and $\mathrm{Mn}$ accumulated in all treatments were increased from 42 to $70 \mathrm{DAE}$, i.e., from the beginning of $R_{7}$ until the beginning of the $R_{8}$ stage, but remained stable in the following stages (Figures 2c, 3c, and 4c). Only in the treatments without fertilization (PD0 and AD0) and with intermediate NPK fertilization (PD1 and $\mathrm{AD} 1$ ), the amounts of $\mathrm{Zn}$ and $\mathrm{B}$ accumulated in reproductive structures increased up to $70 \mathrm{DAE}$ (Figures 1c and 5c). In treatments with $100 \%$ of recommended NPK fertilization, the accumulation of $\mathrm{B}$ and $\mathrm{Zn}$ in reproductive structures increased up to the end of the crop cycle. In most treatments a well defined pattern of micronutrient accumulation was observed in the reproductive structures, with higher accumulation rates after flowering (42 DAE) and reaching the maximum rates of accumulation between 50 and $60 \mathrm{DAE}$, i.e., during the intense growth phase of the reproductive structures (Figures 1e, 2e, 3e, 4e, and $5 \mathrm{e}$ ).

The highest amounts of Fe and B accumulated in reproductive structures occurred in treatments with $100 \%$ of recommended NPK fertilization; these amounts were smallest in treatment AD0 and intermediate and similar in the other treatments (Figures 1c and 3c). Higher amounts of $\mathrm{Cu}$ and $\mathrm{Zn}$ were accumulated in the reproductive structures in the treatments with $100 \%$ of recommended NPK fertilization than in the others, but in treatments without and with intermediate NPK fertilization, the amounts of accumulated $\mathrm{Cu}$ and $\mathrm{Zn}$ were very similar, in spite of the higher $\mathrm{Zn}$ accumulations in treatment PD1 (Figures 2c and 5c). The amounts of $\mathrm{Mn}$ accumulated in reproductive structures in the treatment with recommended NPK fertilization were higher than in treatments $\mathrm{PD} 0, \mathrm{AD} 0$, and $\mathrm{AD} 1$ (Figure 4c). Possibly, NPK fertilization induced greater root growth, especially in depth, resulting in the exploitation of a greater volume of soil and, consequently, a greater absorption of micronutrients.

With regard to micronutrient accumulation in the shoot, it was observed that in the first 28 DAE the amounts of micronutrients accumulated were small and did not differ significantly between treatments (Figures 1d, 2d, 3d, 4d, and 5d), which is coincident with data of DM accumulation (Soratto et al., 2013). After flowering, the rates of micronutrient accumulation in shoots showed a great increase, reaching the maximum values during the $\mathrm{R} 7$ stage (42-55 DAE), but decreased in the following stages (Figures 1f, 2f, 3f, 4f, and 5f). Andrade et al. (2009) obtained similar results in a study with four common bean cultivars. At the end of the cycle, the rates of micronutrient accumulation in shoots were negative, due to leaf loss, i.e., a proportion of micronutrients accumulated by common bean during the cycle returned to the soil even before harvest. Thus, when micronutrients are recommended during the development of this crop, this must be supplied to the plants shortly before the beginning of the R7 stage, 
because in this period pods and grains start to grow rapidly (Soratto et al., 2013) and there is a greater demand for micronutrients.

In all treatments, $\mathrm{Cu}, \mathrm{Fe}, \mathrm{Mn}$ and $\mathrm{Zn}$ were accumulated in the shoots up to 70-75 DAE, i.e., up to the beginning of grain filling (Figures $2 \mathrm{~d}, 3 \mathrm{~d}, 4 \mathrm{~d}$, and $5 \mathrm{~d}$ ). Boron absorption occurred up to $80 \mathrm{DAE}$ in the treatments PD2 and AD2 (100\% of recommended NPK fertilization), but in the other treatments this micronutrient was absorbed only up to $70 \mathrm{DAE}$ (Figure $1 d$ ). When treated with the same levels of fertilization, both cultivars accumulated similar amounts of micronutrients in the shoot, but during the reproductive stage, the treatments with $100 \%$ of recommended NPK fertilization always accumulated higher amounts than in the other treatments (on average $167 \mathrm{~g} \mathrm{ha}^{-1} \mathrm{~B}, 58 \mathrm{~g} \mathrm{ha}^{-1} \mathrm{Cu}, 1.405 \mathrm{~g} \mathrm{ha}^{-1} \mathrm{Fe}$, $1.213 \mathrm{~g} \mathrm{ha}^{-1} \mathrm{Mn}$ and $211 \mathrm{~g} \mathrm{ha}^{-1} \mathrm{Zn}$ ) (Figures $1 \mathrm{~d}, 2 \mathrm{~d}$, $3 \mathrm{~d}, 4 \mathrm{~d}$, and $5 \mathrm{~d}$ ). In a study with four common bean cultivars, Andrade et al. (2009) found average values of B (146 $\left.\mathrm{g} \mathrm{ha}^{-1}\right)$ and Fe absorption (1.341 $\left.\mathrm{g} \mathrm{ha}^{-1}\right)$ similar to those obtained in this study, but much lower values of $\mathrm{Cu}$ (33 $\left.\mathrm{g} \mathrm{ha}^{-1}\right), \mathrm{Mn}\left(68 \mathrm{~g} \mathrm{ha}^{-1}\right)$, and Zn (68 g ha-1) absorption. In the treatments with $50 \%$ of recommended NPK fertilization, absorption values were intermediate (around 119, 43, 1,006, 849, and $153 \mathrm{~g} \mathrm{ha}^{-1} \mathrm{~B}, \mathrm{Cu}, \mathrm{Fe}, \mathrm{Mn}$, and $\mathrm{Zn}$, respectively) (Figures 1d, 2d, 3d, 4d, and 5d). In the unfertilized treatments however, the absorption values were lower (per hectare on average $96 \mathrm{~g} \mathrm{~B}, 30 \mathrm{~g} \mathrm{Cu}, 706 \mathrm{~g} \mathrm{Fe}$, $630 \mathrm{~g} \mathrm{Mn}$, and $110 \mathrm{~g} \mathrm{Zn).} \mathrm{Fageria} \mathrm{\&} \mathrm{Souza} \mathrm{(1995)}$ determined the accumulation of micronutrients in common bean shoots during flowering and also found an increase in micronutrient extraction in response to fertilization with macro and micronutrients. These authors related these results to the increase in DM production.

The amounts of $\mathrm{Cu}$ and $\mathrm{Mn}$ accumulated in the shoots in all treatments were higher than the values observed by Fageria \& Souza (1995) for common bean cv. Emgopa 202-Rubi under irrigation. These authors reported accumulated values of $16 \mathrm{~g} \mathrm{ha}^{-1} \mathrm{Cu}$ and 203 $\mathrm{g} \mathrm{ha}^{-1} \mathrm{Mn}$ up to the flowering stage. The amounts of Fe accumulated $\left(1,094 \mathrm{~g} \mathrm{ha}^{-1}\right)$ in common bean by these authors were similar to treatments with $50 \%$ of recommended NPK fertilization, while the accumulation of $\mathrm{Zn}$ (109 $\left.\mathrm{g} \mathrm{ha}^{-1}\right)$ was similar to treatments without fertilization. In treatments with $100 \%$ of recommended NPK fertilization, the amounts of all micronutrients accumulated in the shoot were higher than the values obtained by Fageria \& Souza (1995), possibly, due to a higher yield level, since these authors obtained on average (three years) $2,162 \mathrm{~kg} \mathrm{ha}^{-1}$ of grain yield, i.e., similar to the treatments without fertilization in this study (Table 3). In all treatments, only $\mathrm{Fe}$ absorption showed values lower than the 2,970 $\mathrm{g} \mathrm{ha}^{-1}$ reported by Malavolta \& Lima Filho (1997) for common bean. The values of B (138 $\left.\mathrm{g} \mathrm{ha}^{-1}\right)$ and $\mathrm{Cu}\left(46 \mathrm{~g} \mathrm{ha}^{-1}\right)$ absorption reported by these authors were similar to values observed in treatments with half the recommended NPK fertilization, while the absorption of Mn (563 $\mathrm{g} \mathrm{ha}^{-1}$ ) was similar to that in the unfertilized treatments. In the treatments with $100 \%$ of recommended NPK fertilization, $\mathrm{Zn}$ absorption $\left(224 \mathrm{~g} \mathrm{ha}^{-1}\right)$ was close to values reported by Malavolta \& Lima Filho (1997) for common bean. In general, Barbosa Filho \& Silva (2000) reported that for the production of $1,000 \mathrm{~kg}$ of grain, common bean absorbed about $17 \mathrm{~g}$ $\mathrm{Cu}, 500 \mathrm{~g} \mathrm{Fe}, 94 \mathrm{~g} \mathrm{Mn}$, and $72 \mathrm{~g} \mathrm{Zn}$ up to the flowering stage, i.e., lower amounts than those obtained in this study, in which the grain yield was higher.

Regardless of the treatment, it was observed that micronutrients were taken up in the following order: $\mathrm{Fe}>\mathrm{Mn}>\mathrm{Zn}>\mathrm{B}>\mathrm{Cu}$. Except for B, the order of greater absorption obtained in all treatments was similar to that observed by other authors, which determined the micronutrient extraction by this crop only at the flowering stage (Fageria, 1989; Fageria \& Souza, 1995; Barbosa Filho \& Silva, 2000). Andrade et al. (2009) observed the following order, based on the average of four common bean cultivars: $\mathrm{Fe}>\mathrm{B}>$ $\mathrm{Mn}>\mathrm{Zn}>\mathrm{Cu}$. The greater $\mathrm{Fe}$ and $\mathrm{Mn}$ absorption was a result of higher accumulation rates compared with other micronutrients (Figures 1d, 1f, 2d, 2f, 3d, $3 \mathrm{f}, 4 \mathrm{~d}, 4 \mathrm{f}, 5 \mathrm{~d}$, and $5 \mathrm{f}$ ).

Highest $\mathrm{B}$ concentrations were observed in grains in treatment PD0, while treatments PD1 and AD1 showed lower and the other treatments intermediate concentrations (Table 3). Copper concentration in grains was not influenced by treatments, while Fe concentration showed a significant difference only between treatment AD2 (191.1 mg kg-1) and PD0 $\left(124.3 \mathrm{mg} \mathrm{kg}^{-1}\right)$. This indicates that NPK fertilization increased Fe concentration in grains of common bean. Andrade et al. (2004) found no differences between $\mathrm{Cu}$ and Fe concentrations in "Pérola" grain, of plants treated with three levels of NPK fertilization. Higher Fe concentrations in the grains could be an interesting aspect, since common bean is an important source of this nutrient in the human diet (Moura \& CinniattiBrazaca, 2006).

The Mn grain concentration was lowest in treatment PD2 and highest in $\mathrm{AD} 2$, which differed only from treatments PD2 and AD1 (Table 3). Zinc concentration in grains differed only between treatment $\mathrm{AD} 2$ and $\mathrm{PD} 0, \mathrm{AD} 0$, and $\mathrm{AD} 1$, with highest concentrations in treatment AD2. Despite the variation among treatments, it was observed that $\mathrm{Cu}$ and $\mathrm{Zn}$ concentrations in grains agreed with the values observed by Fageria (1989) in common bean cultivars (Carioca, CNF 10, and CNF 4856) fertilized with different $\mathrm{P}$ levels. However, in this study $\mathrm{Fe}$ and $\mathrm{Mn}$ concentrations in grains were higher than the values observed by Fageria (1989). This author obtained $\mathrm{Cu}$, $\mathrm{Fe}, \mathrm{Mn}$, and $\mathrm{Zn}$ concentrations ranging from 6 to 13 , 30 to 70,8 to 19 , and 17 to $47 \mathrm{mg} \mathrm{kg}^{-1}$, respectively. This difference between the results of this study and those of Fageria (1989) may be due to differences among the cultivars used. In a study on yield and 
nutritional quality of common bean cultivars grown under different levels of NPK fertilization, the Zn concentration in grains was not increased by NPK fertilization, while $\mathrm{Cu}, \mathrm{Fe}$, and $\mathrm{Mn}$ concentrations did

Table 3. Nutrient concentration in grain, nutrient exportation per area, nutrient exportation per ton of grain, and relative nutrient exportation by common bean cultivars, under different levels of fertilization

\begin{tabular}{|c|c|c|c|c|c|}
\hline Treatment $^{(1)}$ & $\mathbf{B}$ & $\mathbf{C u}$ & $\mathbf{F e}$ & Mn & $\mathbf{Z n}$ \\
\hline & \multicolumn{4}{|c|}{ Grain concentration, $\mathrm{mg} \mathrm{kg}{ }^{-1}$} & \\
\hline PD0 & $31.7 \mathrm{a}$ & $7.5 \mathrm{a}$ & $124.3 \mathrm{~b}$ & $132.2 \mathrm{ab}$ & $22.5 \mathrm{~b}$ \\
\hline PD1 & $22.8 \mathrm{c}$ & $7.5 \mathrm{a}$ & $152.9 \mathrm{ab}$ & $136.2 \mathrm{ab}$ & $25.7 \mathrm{ab}$ \\
\hline PD2 & $25.7 \mathrm{bc}$ & $7.4 \mathrm{a}$ & $164.5 \mathrm{ab}$ & $91.1 \mathrm{c}$ & $27.4 \mathrm{ab}$ \\
\hline $\mathrm{AD} 0$ & $25.3 \mathrm{bc}$ & $7.4 \mathrm{a}$ & $169.1 \mathrm{ab}$ & $150.5 \mathrm{ab}$ & $23.6 \mathrm{~b}$ \\
\hline $\mathrm{AD} 1$ & $21.3 \mathrm{c}$ & $8.3 \mathrm{a}$ & $162.5 \mathrm{ab}$ & $127.8 \mathrm{~b}$ & $23.5 \mathrm{~b}$ \\
\hline $\mathrm{AD} 2$ & $29.0 \mathrm{ab}$ & $8.3 \mathrm{a}$ & $191.1 \mathrm{a}$ & $160.4 \mathrm{a}$ & $31.3 \mathrm{a}$ \\
\hline \multirow[t]{2}{*}{$\mathrm{CV}(\%)$} & 13.9 & 14.5 & 20.3 & 15.6 & 17.7 \\
\hline & \multicolumn{4}{|c|}{ Exportation per area, $\mathrm{g} \mathrm{ha}^{-1}$} & \\
\hline PD0 & $55 \mathrm{~b}$ & $14 \mathrm{c}$ & $222 \mathrm{c}$ & $234 \mathrm{~d}$ & $40 \mathrm{~d}$ \\
\hline PD1 & $58 \mathrm{~b}$ & $20 \mathrm{~b}$ & $388 \mathrm{~b}$ & $354 \mathrm{~b}$ & $68 \mathrm{~b}$ \\
\hline PD2 & 89 a & $26 \mathrm{a}$ & 549 a & $313 \mathrm{c}$ & $92 \mathrm{a}$ \\
\hline $\mathrm{AD} 0$ & $38 \mathrm{c}$ & $12 \mathrm{c}$ & $267 \mathrm{c}$ & $245 \mathrm{~d}$ & $41 \mathrm{~d}$ \\
\hline $\mathrm{AD} 1$ & $50 \mathrm{~b}$ & $18 \mathrm{~b}$ & $381 \mathrm{~b}$ & $294 \mathrm{c}$ & $52 \mathrm{c}$ \\
\hline $\mathrm{AD} 2$ & $90 \mathrm{a}$ & $26 \mathrm{a}$ & $568 \mathrm{a}$ & $467 \mathrm{a}$ & $96 \mathrm{a}$ \\
\hline \multirow[t]{2}{*}{$\mathrm{CV}(\%)$} & 10.0 & 10.3 & 13.5 & 7.3 & 10.9 \\
\hline & \multicolumn{5}{|c|}{ Exportation per ton of grain, $\mathrm{g}$ ton $^{-1(2)}$} \\
\hline PD0 & $27.6 \mathrm{a}$ & $6.5 \mathrm{a}$ & $108.1 \mathrm{~b}$ & $115.0 \mathrm{ab}$ & $19.6 \mathrm{~b}$ \\
\hline PD1 & $19.8 \mathrm{c}$ & $6.5 \mathrm{a}$ & $133.0 \mathrm{ab}$ & $118.5 \mathrm{ab}$ & $22.4 \mathrm{ab}$ \\
\hline PD2 & $22.4 \mathrm{bc}$ & $6.5 \mathrm{a}$ & $143.1 \mathrm{ab}$ & $79.2 \mathrm{c}$ & $23.9 \mathrm{ab}$ \\
\hline $\mathrm{AD} 0$ & $22.0 \mathrm{bc}$ & $6.5 \mathrm{a}$ & $147.1 \mathrm{ab}$ & $130.9 \mathrm{ab}$ & $20.6 \mathrm{~b}$ \\
\hline $\mathrm{AD} 1$ & $18.6 \mathrm{c}$ & $7.2 \mathrm{a}$ & $141.3 \mathrm{ab}$ & $111.2 \mathrm{~b}$ & $20.4 \mathrm{~b}$ \\
\hline $\mathrm{AD} 2$ & $25.2 \mathrm{ab}$ & $7.3 \mathrm{a}$ & $166.2 \mathrm{a}$ & $139.6 \mathrm{a}$ & $27.3 \mathrm{a}$ \\
\hline \multirow[t]{2}{*}{$\mathrm{CV}(\%)$} & 14.0 & 15.2 & 19.0 & 14.6 & 19.8 \\
\hline & \multicolumn{5}{|c|}{ Relative exportation, $\%^{(3)}$} \\
\hline PD0 & 51 & 45 & 31 & 36 & 35 \\
\hline PD1 & 45 & 43 & 37 & 41 & 40 \\
\hline PD2 & 55 & 47 & 41 & 27 & 46 \\
\hline $\mathrm{AD} 0$ & 43 & 41 & 39 & 40 & 39 \\
\hline $\mathrm{AD} 1$ & 45 & 45 & 40 & 35 & 38 \\
\hline $\mathrm{AD} 2$ & 52 & 42 & 38 & 37 & 43 \\
\hline Média & 49 & 44 & 38 & 36 & 40 \\
\hline
\end{tabular}

Values followed by same letter in columns, are not significantly different at $\mathrm{p} \leq 0.05$ by the LSD test. ${ }^{(1)}$ PD0: Pérola without NPK fertilization, PD1: Pérola with $50 \%$ of recommended NPK fertilization; PD2: Pérola with $100 \%$ of recommended NPK fertilization; AD0: IAC Alvorada without NPK fertilization, AD1: IAC Alvorada with $50 \%$ of recommended NPK fertilization; AD2: IAC Alvorada with $100 \%$ of recommended NPK fertilization. ${ }^{(2)}$ Data based on grain yield (Soratto et al., 2013) and the values of maximum nutrient accumulation see figures $1,2,3,4$ and $5 .{ }^{(3)}$ Relative nutrient exportation in relation to maximum amounts absorbed, see figures $1,2,3,4$ and 5 . increase (Andrade et al., 2004). According to these authors, it is important to know the concentration of micronutrients in common bean grains, once $\mathrm{Zn}, \mathrm{Fe}$, $\mathrm{Cu}$, and $\mathrm{Mn}$ are considered essential to the diet of humans and animals, being required for many body functions and since they may be found at deficient, excessive or unbalanced levels in the diet (Andrade et al., 2004).

Regardless of the cultivar used, the treatments with $100 \%$ of recommended NPK fertilization showed higher values of exportation per area for all micronutrients (Table 3). According to Malavolta \& Lima Filho (1997) in a grain production of $1,500 \mathrm{~kg} \mathrm{ha}^{-1}$ of common bean, the exported amounts of micronutrients are around $54,18,120,50$, and $76 \mathrm{~g} \mathrm{ha}^{-1}$ of $\mathrm{Cu}, \mathrm{Fe}, \mathrm{Mn}$, and $\mathrm{Zn}$, respectively. Although the values of exportation of $\mathrm{B}$, $\mathrm{Cu}$, and $\mathrm{Zn}$ reported by these authors agree with the values observed in this study, they are relatively high, since the grain yield obtained by Malavolta \& Lima Filho (1997) was lower than in this experiment (Soratto et al., 2013). Pessoa et al. (2000), in a study with common bean, cv. Ouro Negro with a grain yield of $1,893 \mathrm{~kg} \mathrm{ha}^{-1}$, observed exported amounts per hectare of $25 \mathrm{~g} \mathrm{Cu}, 102 \mathrm{~g} \mathrm{Fe}, 23 \mathrm{~g} \mathrm{Mn}$, and $63 \mathrm{~g} \mathrm{Zn}$. Barbosa Filho \& Silva (2000) obtained average values of exportation per hectare of $25 \mathrm{~g}$ of $\mathrm{Cu}, 175 \mathrm{~g}$ of $\mathrm{Fe}$, $39 \mathrm{~g}$ of $\mathrm{Mn}$, and $25 \mathrm{~g} \mathrm{Zn}$, for a grain yield around $2,500 \mathrm{~kg} \mathrm{ha}^{-1}$, i.e., with lower exportations of $\mathrm{Fe}, \mathrm{Mn}$, and $\mathrm{Zn}$ than found in this study.

The largest $B$ exportation per ton of grain occurred in the PD0 treatment, followed by treatment AD2, which showed no significant difference from treatments PD2 and AD0 (Table 3). The lowest B exportation per ton was observed in treatments PD1 and $\mathrm{AD} 1$, i.e., $\mathrm{B}$ exportation had no relationship with grain yield (Soratto et al., 2013), since treatment PD0 with low yield showed higher exportations per ton than most treatments with a higher grain yield. Copper exportation per ton of grain was not affected by treatments, demonstrating that the exportation of this nutrient was greater with an increase in grain yield, as may be observed by the values of grain yield (Soratto et al., 2013) and exportation per area (Table 3). Except for treatment AD2, in the other treatments $\mathrm{Fe}$ and $\mathrm{Zn}$ exportations per ton of grain showed no significant differences, indicating that the exportation of these micronutrients is related to grain yield, i.e., when the yield level is increased, the exportation per area is increased. Manganese exportation per ton of grains differed only between treatment AD2 (139.6 $\left.\mathrm{g} \mathrm{t}^{-1}\right)$ and treatments AD1 (111.2 $\mathrm{g} \mathrm{t}^{-1}$ ) and PD2 (79.2 $\mathrm{g} \mathrm{t}^{-1}$ ), i.e., the amount of Mn exported was not related to grain yield (Soratto et al., 2013), since treatment PD2, one of those with highest grain yield did not show the greatest exportation, as a result of the low concentrations of this nutrient in grains (Table 3).

Despite the variations between treatments, on average approximately half of all B absorbed by 
common bean during the cycle is exported with the grains, while for the other micronutrients this proportion is lower, i.e., on average between 56 and $64 \%$ of the amounts absorbed during the cycle return to the soil with crop residues (Table 3 ). This explains, in part, why even in the treatments without micronutrient application, and including those in which a higher level of NPK fertilization was used, the levels of micronutrient concentration in leaves were appropriate or even higher than recommended for this crop (Ambrosano et al., 1997). This provided a satisfactory grain yield (Soratto et al., 2013), i.e., above $1,800 \mathrm{~kg} \mathrm{ha}^{-1}$, even in the treatments without NPK fertilization.

\section{CONCLUSIONS}

1. Higher levels of NPK fertilization increased micronutrient extraction by the cultivars Pérola and IAC Alvorada, and the treatments with $100 \%$ of the recommended NPK fertilization promoted an average extraction of $167 \mathrm{~g} \mathrm{~B}, 58 \mathrm{~g} \mathrm{Cu}, 1,405 \mathrm{~g} \mathrm{Fe}, 1,213 \mathrm{~g}$ $\mathrm{Mn}$, and $211 \mathrm{~g} \mathrm{Zn}$ per hectare.

2. Regardless of the treatment, the period of highest demand for $\mathrm{B}, \mathrm{Cu}, \mathrm{Fe}, \mathrm{Mn}$, and $\mathrm{Zn}$ of both cultivars occurred between 42 and $55 \mathrm{DAE}$, i.e., at pod formation $\left(\mathrm{R}_{7}\right)$, showing that in case of micronutrient deficiency, applications must be provided to ensure a higher availability to the plants in this period.

3. The amount of $\mathrm{B}, \mathrm{Cu}, \mathrm{Fe}, \mathrm{Mn}$, and $\mathrm{Zn}$ exported depended mainly on the level of NPK fertilization used, with values per hectare ranging from 38 to $90 \mathrm{~g}$ of $\mathrm{B}$, 12 to $26 \mathrm{~g}$ of $\mathrm{Cu}, 222$ to $568 \mathrm{~g}$ of $\mathrm{Fe}, 234$ to $467 \mathrm{~g}$ of $\mathrm{Mn}$, and 40 to $96 \mathrm{~g}$ of $\mathrm{Zn}$.

\section{ACKNOWLEDGEMENTS}

The authors are indebted to the National Council for Scientific and Technological Development (CNPq) for a research award to the second author and thank the State of São Paulo Research Foundation (FAPESP) for financial support and a scholarship to the third author (Proc. 2010/18602-9).

\section{LITERATURE CITED}

AMBROSANO, E.J.; TANAKA, R.T.; MASCARENHAS, A.A.; RAIJ, B.van; QUAGGIO, J.A. \& CANTARELLA, H. Leguminosas e oleaginosas. In: RAIJ, B.van; CANTARELA, H.; QUAGGIO, J.A. \& FURLANI, A.M.C., eds. Recomendações de adubação e calagem para o Estado de São Paulo. Campinas, Instituto Agronômico de Campinas, 1997. p.189-204. (Boletim Técnico 100)
ANDRADE, C.A.B.; PATRONI, S. M.S.; CLEMENTE, E. \& SCAPIM, C.A. Produtividade e qualidade nutricional de cultivares de feijão em diferentes adubações. Ci. Agrotec., 28:1077-1086, 2004.

ANDRADE, M.J.B.; VIEIRA, N.M.B.; ALVES, A.F. \& CARVALHO, L.P. Accumulation of micronutrients by different common bean cultivars grown in different plant densities in conventional crop system. Ann. Rep. Bean. Improv. Coop., 52:122-133, 2009.

ASCOLI, A.A.; SORATTO, R.P. \& MARUYAMA, W.I. Aplicação foliar de molibdênio, produtividade e qualidade fisiológica de sementes de feijoeiro irrigado. Bragantia, 67:377-384, 2008.

BARBOSA FILHO, M.P. \& SILVA, O.F. Adubação e calagem para o feijoeiro irrigado em solo de cerrado. Pesq. Agropec. Bras., 35:1317-1324, 2000.

BARBOSA, F.R. \& GONZAGA, A.C.O., eds. Informações técnicas para o cultivo do feijoeiro-comum na Região Central-Brasileira: 2012-2014. Santo Antônio de Goiás, Embrapa Arroz e Feijão. 2012. 247p. (Documentos, 272)

COBRA NETTO, A.; ACCORSI, W.R. \& MALAVOLTA, E. Estudos sobre a nutrição mineral do feijoeiro (Phaseolus vulgaris L. var. Roxinho). Anais ESALQ, 28:257-274, 1971.

DECHEN, A.R. \& NACHTIGALL, G.R. Micronutrientes. In: FERNANDES, M.S., ed. Nutrição mineral de plantas. Viçosa, MG, Sociedade Brasileira de Ciência do Solo, 2006. p.328-352.

EMPRESA BRASILEIRA DE PESQUISA AGROPECUÁRIA EMBRAPA. Sistema brasileiro de classificação de solos. 2.ed. Rio de Janeiro, Embrapa Solos, 2006. 306p.

FAGERIA, N.K. \& SOUZA, N.P. Respostas das culturas de arroz e feijão em sucessão a adubação em solo de cerrado. Pesq. Agropec. Bras., 30:359-368, 1995.

FAGERIA, N.K. Effects of phosphorus on growth, yield and nutrient accumulation in common bean. Trop. Agric. $66: 249-255,1989$

FERNANDES, D.S.; SORATTO, R.P.; KULCZYNSKI, S.M.; BISCARO, G.A. \& REIS, C.J. Produtividade e qualidade fisiológica de sementes de feijão em conseqüência da aplicação foliar de manganês. Pesq. Agropec. Bras., 42:419-426, 2007.

FERNÁNDEZ, F.; GEPTS, P. \& LOPES, M. Etapas de desarrollo de la planta de frijol (Phaseolus vulgaris L.). Cali, Centro Internacional de Agricultura Tropical, 1986. 34p.

GALLO, J.R. \& MIYASAKA, S. Composição química do feijoeiro e absorção de elementos nutritivos, do florescimento à maturação. Bragantia, 20:867-884, 1961.

HAAG, H.P.; MALAVOLTA, E.; GARGANTINI, H. \& BLANCO, H.G. Absorção de nutrientes pela cultura do feijoeiro. Bragantia, 26:381-391, 1967.

KIRKBY, E.A. \& RÖMHELD, V. Micronutrientes na fisiologia de plantas: Funções, absorção e mobilidade. Piracicaba, INPI, 2007. 24p. (Encarte de Informações Agronômicas, 118) 
MALAVOLTA, E. \& LIMA FILHO, O.F. Nutrição e adubação do feijoeiro. In: FANCELLI, A.L. \& DOURADO-NETO, D., eds. Tecnologia da produção do feijão irrigado. Piracicaba, ESALQ-USP, 1997. p.22-51.

MALAVOLTA, E.; VITTI, G.C. \& OLIVEIRA, S.A. Avaliação do estado nutricional de plantas: Princípios e aplicações. Piracicaba, Potafos, 1997. 308p.

MALAVOLTA, E. Manual de nutrição mineral de plantas. São Paulo, Agronômica Ceres, 2006. 638p.

MOURA, N.C. \& CINNIATTI-BRAZACA, S.G. Avaliação da disponibilidade de ferro de feijão comum (Phaseolus vulgaris $\mathrm{L}$.) em comparação com carne bovina. Ci. Tecnol. Alim., 26,:270-276, 2006.

OLIVEIRA, I.P.; ARAÚJO, R.S. \& DUTRA, L.G. Nutrição mineral e fixação biológica de nitrogênio. In: ARAÚJO, R.S.; RAVA, C.A.; STONE, L.F. \& ZIMMERMANN, M.J.O., coords. Cultura do feijoeiro comum no Brasil. Piracicaba, Potafos, 1996. p.169-221.

PESSOA, A.C.S.; RIBEIRO, A.C.; CHAGAS, J.M. \& CASSINI, S.T.A. Concentração foliar de molibdênio e exportação de nutrientes pelo feijoeiro "Ouro Negro" em resposta à adubação foliar com molibdênio. R. Bras. Ci. Solo, 24:75$84,2000$.

RAIJ, B.van; ANDRADE, J.C.; CANTARELLA, H. \& QUAGGIO, J.A. Análise química para avaliação da fertilidade de solos tropicais. Campinas, Instituto Agronômico de Campinas, 2001. 284p.
RAIJ, B.van; QUAGGIO, J.A.; CANTARELLA, H. \& ABREU, C.A. Interpretação de resultados de análise de solo. In: RAIJ, B.van; CANTARELLA, H.; QUAGGIO, J.A. \& FURLANI, A.M.C., eds. Recomendações de adubação e calagem para o Estado de São Paulo. Campinas, Instituto Agronômico de Campinas, 1997. p.8-13. (Boletim Técnico, 100)

ROSOLEM, C.A. Nutrição e adubação do feijoeiro. Piracicaba, Potafos,1987. 93p.

SORATTO, R.P. \& CRUSCIOL, C.A.C. Dolomite and phosphogypsum surface application effects on annual crops nutrition and yield. Agron. J., 100:261-270, 2008.

SORATTO, R.P.; FERNANDES, A.M.; SANTOS, L.A. \& JOB, A.L.G. Extração e exportação de nutrientes em cultivares de feijoeiro sob níveis de adubação: I - Macronutrientes. R. Bras. Ci. Solo, 37: p.1027-1042, 2013.

TEIXEIRA, I.R.; BORÉM, A.; ANDRADE, M.J.B.; GIÚDICE, M.P.D. \& CECON, P.R. Teores de clorofila em plantas de feijoeiros influenciadas pela adubação com manganês e zinco. Acta Sci. Agron., 26:147-152, 2004.

VIEIRA, C. Adubação mineral e calagem. In: VIEIRA, C.; PAULA JÚNIOR, T.J. \& BORÉM, A., eds. Feijão. 2.ed. Viçosa, MG, Universidade Federal de Viçosa, 2006. p.115142.

WOOD, L.J.; MURRAY, B.J.; OKATAN, Y. \& NOODÉN, L.D. Effect of petiole phloem distribution on starch and mineral distribution in senescing soybean leaves. Am. J. Bot., 73:1377-1383, 1986. 